\title{
Análise ergonômica do setor da biblioteca da Unochapecó
}

Carine Ariéli Grings

Bruna Taciara Radin

Carla Letícia Peripolli

Rosane Polli

Josiane Altemar
CADERNO DE RESUMOS

FisiSenectus. Unochapecó Ano 1 - Edição especial - 2013 p. 129

Carine Ariéli Grings, acadêmica do $6^{\circ}$ período do curso de Fisioterapia da Universidade Comunitária da Região de Chapecó (Unochapecó), gringsca@unochapeco.edu.br

\section{Resumo}

Introdução: A análise ergonômica compreende a adaptação das condições de trabalho às características dos trabalhadores, visando proporcionar um máximo de conforto, segurança e desempenho eficiente, adaptando o ambiente ao homem e não o homem ao ambiente. Ressalta-se que a Ergonomia contribui para o planejamento, projeto e avaliação das tarefas desenvolvidas pelo homem, de modo a torná-las compatíveis com as necessidades, habilidades e limitações das pessoas. Objetivos: Analisar ergonomicamente as condições de trabalho no setor da biblioteca da Unochapecó, em específico no departamento de processamento técnico. Metodologia: O processo da análise contemplou três momentos, o primeiro foi a coleta de assinatura de solicitação por parte da coordenadora do setor da biblioteca, o segundo foi a assinatura do termo de uso de imagem e voz por parte das duas funcionárias avaliadas e o terceiro a análise ergonômica baseada em alguns instrumentos como o Checklist para análise das condições do posto de trabalho ao computador, fotos e filmagens. Resultados: Foram analisados diversos itens no posto de trabalho, dentre eles a avaliação da cadeira, do apoio para os pés, e da iluminação do ambiente que estes obtiveram um percentual de $100 \%$, demonstrando condições ergonômicas excelentes. Em relação à mesa de trabalho o percentual atingido foi $83 \%$, demonstrando condições ergonômicas boas, já o teclado, perfez um total de $40 \%$, mostrando condições ergonômicas ruins. 0 monitor de vídeo apresentou 70\% evidenciando condições laborais razoáveis e no que diz respeito à análise da disposição da sala a mesma alcançou 73\%, sendo considerada uma condição boa, logo a avaliação do sistema de trabalho, obteve 33\%, classificando-se nas condições ruins de trabalho.

Considerações finais: Observa-se que, com os dados obtidos, as condições ergonômicas do setor avaliado encontram-se boas, uma vez que atingiu um percentual total de $71,96 \%$. Contudo, é relevante instituir orientações para o uso correto da mobília disponível para diminuir os riscos ergonômicos no ambiente de trabalho.

\section{Palavras-chave}

Riscos. Ergonomia. Saúde do trabalhador. 